\title{
COST AND BENEFITS OF RUNNING A TEA-BASED FARMER FIELD SCHOOL IN KENYA
}

Stephen Wambugu Maina

Ministry of Agriculture, Nakuru, Kenya

E-mail: stephen67maina@yahoo.com

John Gowland-Mwangi

Egerton University, Egerton, Kenya

Email: mwangijg5@yahoo.com,dvcre@egerton.ac.ke

Dave Boselie

Learning and Innovation, IDH, The Sustainability Initiative Utrecht, The Netherlands Email: Boselie@idhsustainabletrade.com

\begin{abstract}
The Kenya Tea Development Agency (KTDA), through its extension workers, has been educating tea producers on good agricultural practices using Farmer Field Schools (FFS). Information on training cost and benefits of running a tea-based FFS in Kenya were not readily available. Such information would enable tea stakeholders to develop a strategy for up-scaling FFS. This study sought to determine and describe the cost and benefits of running a tea-based FFS among small-scale farmers in the Rift Valley. The study used a Cross-Sectional research design to collect data from 514 small-scale tea growers drawn randomly from KTDA factories. A questionnaire with a reliability coefficient of $0.92 \alpha$ was used after validation by extension experts. Face-to-Face interviews and a stakeholders' workshop were used for triangulation purposes. Data were analyzed qualitatively and reported using descriptive statistics. The results indicated that training a farmer in a tea-based FFS in a year costs Ksh 6,076/=(US\$71). The training gave farmers skills to improve their tea husbandry, yields, level of empowerment and leadership skills. The researchers concluded that training tea farmers in FFSs was cheap, sustainable and effective in changing their behavior. Stakeholders in the tea-value chain should increase funding and use of FFS in training tea farmers.
\end{abstract}

Key words: benefits, cost, farmer field schools, good agricultural practices, Kenya Tea Development Agency.

\section{Introduction}

Agriculture is the backbone of Kenya's economy contributing $26 \%$ directly and another $25 \%$ indirectly of the GDP, accounting for $65 \%$ of Kenya's total exports and provides more than $18 \%$ of formal employment (Government of Kenya, 2010). Tea is a key foreign exchange earner and in 2009, the value of tea exports was Kenya shillings $69 /=$ (US\$ 0.86) billion (Government of Kenya, 2011; Mugambi, 2010; Odhiambo, 2010). Kenya is the World's third largest tea producer and the world's largest exporter of black tea with approximately 110,000 hectares of land under tea that is world famous for its brightness, attractive color, brisk, flavor and texture (Maina et al., 2012a; Mutai, 2011). Kenya Tea Development Agency (KTDA) is the second largest exporter of black tea in the world and is responsible for $62 \%$ of all tea produced 
PROBLEMS

OF EDUCATION

IN THE $21^{\text {st }}$ CENTURY

Volume 47, 2012

in Kenya (Braga, Lonescu-Somer, Seifert, 2011). Since 2006, KTDA extension workers have been using Farmer Field Schools (FFSs) to educate its smallholder tea producers in soft and technical skills (Campbell, 2010; Maina et al., 2012b; Odhiambo, 2010). Farmer Field School popularly known as "informal" or "school without walls" is a community-based, capacity building, learning by doing extension model or system that uses adult education principles in farmers' groups (Akinnagbe \& Ajayi, 2010). This group-based experiential learning encourages farmers (normally in groups of 20-30) to learn improved technologies and farming practices through observation (Hartl, 2009; Mwangi, Oloo \& Maina 2010). The experiential learning approach and empowerment - that refers to the development of skills so that individuals can make informed choices in their lives - make FFS a popular training method for farmers and provides an up-scaling model for knowledge empowerment (Dzeco, Amilai \& Cristóvão, 2010; Stigter, 2010). The FFS can be an effective methodology for building trainers' capacity and changing their attitudes (Maina et al., 2012a).

\section{Problem of Research}

The Kenya Tea Development Agency (KTDA) extension workers have been training small-scale tea (Camellia sinensis) producers through various extension methodologies to adopt good agricultural practices (GAPs). Tea growers' adoption of GAPs through the conventional method of extension has been slow. The KTDA extension workers from the year 2006 started educating tea producers on good agricultural practices using the FFS approach. Most FFS initiatives got financial support from KTDA tea factories but were expected to be self-sustaining as the FFSs are up-scaled to reach 560,000 tea producers. However, information on the cost and benefits of running a tea - based FFS were not readily available. This study sought to provide the missing information in order to assist tea stakeholders' to mobilize enough training resources for the up-scaling of FFSs.

\section{Research Focus}

Limited education, knowledge transfer and adoption by farmers of improved technologies are largely responsible for reduced farm productivity, farmers' inability to generate income, poverty and food insecurity (Kilimo Trust, 2010; Maina, Mwangi, Boselie, Onduru \& Buses, 2012a). The KTDA factories have used FFS since 2006 to train farmers in sustainable tea production and aim to reach 560,000 tea producers using this methodology (Braga, LonescuSomer \& Seifert, 2011; Hiller, Onduru, \& Jager, 2009). This flexible, participant-led learning facilitates their demand for knowledge and enables them to choose, test and adapt useful technologies based on their needs (Mwangi, Oloo \& Maina, 2010). The FFS provides a forum for participant-led learning, flexible interactions and integration of different types of knowledge. The FFSs may be expensive or low-cost depending on who implements them and how they are conducted but costs per FFS decline as activities become routine, prices become lower due to bulk purchase of materials, and trainer and facilitator skills and experience increase (Braun \& Duveskog, 2010; Maina et al., 2012b). The costs of up-scaling FFSs include expenses for training extension workers and for buying inputs for running FFS. It is possible to up-scale the FFS system to many farmers by deploying FFS-trained farmers to train other farmers (Bunyatta et al., 2006). The FFS graduates are selected and appointed as FFS farmer facilitators that carry the knowledge gained in FFSs as farmer facilitators to new FFS groups in the community. Tea smallholder farmers can also be trained through demonstrations in field day that lasts for one to several days and normally attended by several hundred farmers. Field days' costs are related to the opportunity cost of the trainers' time, transportation of experts to the field day and participants' food, refreshments and time (Ricker-Gilbert, 2005). Other field day costs include 
those related to presentation stage (dais) and publicity banners (Ricker-Gilbert, 2005). Tea farmers can also be trained through farm visits. A farm visit uses the training and visit (T\&V) extension approach. The T\&V system is a technology transfer extension model that was used in the mid -1970s to mid -1990s, by 70 countries in Asia and Sub-Saharan Africa (Swanson \& Rajalahti, 2010; Wani, 2008). In the approach, tea extension agents (TESAs) living in KTDA factories and farmers' neighborhoods visited local tea farmers individually and passed "proven tea practices" (recommendations) from tea research centers to contact farmers (Maina et al., 2012b; Swanson \& Rajalahti, 2010; Wani, 2008). Farmers also incurred an opportunity cost for the time spent in training.

Farmers who joined FFS benefited from income generating activities, enjoyed benefits accruing from FFS activities, networking, social capital and facilitators' expertise (Wanyama, Mose, Mutoko, Wanyonyi, Nyambati, Wanjekeche \& Rono, 2007). Participation in FFSs made farmers more efficient and self-reliant managers of their scarce agricultural resources. FFSs gave farmers practical knowledge and skills to work more effectively (Muller, Guenat \& Fromm, 2010). Being an agricultural extension model, the FFS plays a key role in raising farm productivity by being a means for offering technical advice, helping farmers identify problems and opportunities, sharing information and supporting group formation (Asian Productivity Organization, 2006). Using the FFS for training groups of farmers can lead to sustainability of the groups because it allows the groups to build sustainable human and social capital, which include collective marketing of produce, and lobbying through farmer networks and savings groups (Davis, Nkonya, Mekonnen, Odedo, Miiro \& Nkuba, 2010). Acquisition of knowledge, better attitudes and skills for problem-solving empower FFS-participating farmers while professionally-trained facilitators make farmers feel confident to share their knowledge, skills and experiences (Davis, et al., 2010).

Several concepts drawn from non-formal adult education concepts are relevant to the FFS approach. This study looks at the FFS approach adapted to suit studies on tea, tea-related technologies and the environment under which tea is grown in Kenya. The FFs learning approach is informed by a combination of concepts and theories (FAO, 2011). These theories include the Constructivist theory, Haberman's critical theory, Knowles concept of adult education, Kolbs learning cycle of experiential learning, Carl Rogers' work on learner-centered approaches, Action learning theory, Mezirow's transformative learning theory, Stimulus-response theory, Cognitive theory and Motivation and Personality theory. Transformative learning theory, which is based on the assumption that adult learners are active with significant life experience that can enable them construct meaning of what happens in their lives, is the most established theory of adult learning (De Jager et al., 2009; Friis-Hansen, Duveskog, \& Taylor, 2012).

\section{Methodology of Research}

\section{General Background of Research}

A Cross-Sectional Survey Design, which is the scientific method for collecting and analyzing data gathered from two or more samples at one point in time (Mosby's Dental Dictionary, 2008) was used to collect both qualitative and quantitative data from smallholder tea producers. To help ensure an accurate and comprehensive investigation, Face-to-face interviews, document analysis, record reviews, site visits, observation, living the system and a stakeholders' workshop were carried out. The study was undertaken in 25 KTDA factories located East and West of Kenya's Rift Valley, which divides the country right in the middle between East and West. Data was collected from KTDA factories in Embu, Meru, Kiambu, Murang'a, Kirinyaga and Nyeri counties in the East while those in the West are in Kericho, Bomet, Vihiga, Nandi, Mt Elgon, Nyamira and Kisii counties. These areas have tea as a major economic activity, most 
PROBLEMS

OF EDUCATION

IN THE $21^{\text {st }}$ CENTURY

Volume 47, 2012

of the tea growers were small-scale farmers that delivered their tea to KTDA factories, Farmers Field School were being used as a training methodology, and the locations enabled to capture agro-ecological, ethnical, social-cultural diversity that characterized the tea growing areas in Kenya.

\section{Sample of Research}

The target population for this study was all KTDA smallholder tea producers totaling 560,000. A two-stage random sampling technique based on factories and Farmers Field School was used to sample 514 tea growers. A random sample of 25 KTDA factories was selected. A total of 20 FFSs members per factory were randomly selected purposively from FFS groups. A two-stage random sampling provided greater precision, guard against an unrepresentative sample and is less costly (Kothari, 2008). Data was collected from all FFS's' experts and KTDA extension agents in the target area from randomly selected representatives of FFS participants and tea stakeholders.

\section{Instrument and Procedures}

A questionnaire containing closed-ended and open-ended items and two check-lists developed by the researchers was used to collect data from FFS-trained tea growers, FFS facilitators, farmers delivering tea to the 25 selected factories and from stakeholders from KTDA, Rainforest Alliance, Partner Africa, ETC East Africa, Ministry of Agriculture, Egerton University and LEI, part of Wageningen UR. Validity was ascertained by a panel of extension experts while a pilot test involving 30 farmers in Nandi County indicated the questionnaire's reliability coefficient of $\alpha=0.92$ which was above the threshold for acceptable reliability of $\alpha=0.70$, with the significance level set a priori at $\mathrm{p}<0.05$. A research permit was obtained from the Kenya National Council for Science and Technology. The researchers - through a preliminary survey identified experts in FFSs and stakeholders along the tea value chain with whom they worked out logistics for data collection. Tea producers in the selected sample assisted the researchers to define the FFS costs and benefits. Document analysis and Faceto-Face interviews were used to obtain the relevant information based on the objectives of the study. To make data collection easier, faster and more efficient, logistics for Face-to-Face interviews were worked out with stakeholders prior to the actual data collection. Follow-up interviews were conducted to increase the response rate.

\section{Data Analysis}

Data were analyzed qualitatively and reported using descriptive statistics. It was expressed in charts and tables. Descriptive statistics were used to calculate the costs.

\section{Results of Research}

On average the farmers interviewed had been active members of a tea-based FFS for 11.67 months (standard deviation: 13.01; mode: 12 months) while the longest period that they had been active FFS members was 79 months. Most of the FFS registered by the Ministry of Culture and Social Services had 30 members; the average was 28 and the maximum of 44 . The number of active FFS members was 21, standard deviation of 8.31, mode of 30 and maximum of 35 members. The mean earnings for a smallholder farmer was three hundred $(300 /=)$ Kenya shillings per day, standard deviation of 365.05 , mode of $200 /=$ and maximum of $3,750 /=$. The mean number of hours worked per day was 7 , standard deviation of 2.49 , mode of 8 hours and 
a maximum of 12 hours. It was observed that an FFS usually started with at least 30 members but this number gradually decreased to an average of about 21 members. This decrease was

PROBLEMS

OF EDUCATION

IN THE $21^{\text {st }}$ CENTURY

Volume 47, 2012

due to reasons such as unfulfilled expectations, poor FFS leadership, and engagement in more rewarding opportunities or changing priorities. It was also noted that farmers whose FFS was registered were able to access credit facilities from the government and were able to benefit from being linked to groups having similar interests and activities as well as to groups that offered training opportunities.

The cost of setting up and running a Farmer Field School varies depending on the enterprise and the cost of facilitators and the materials required for training. Table1 indicates the cost of conducting a tea-based FFS in Kenya for 12 months based on the 2011 prices as derived from KTDA field staff and smallholder farmer respondents. In the study area, the average cost of hiring a venue per year was Kenya shillings 17,100/=. Money was also spent to buy stationery (e.g., a flip charts was bought $400 /=$ Kenya shillings, exercise books at $675 /=$, pens at $675 /=$, file folder at $675 /=$, felt pens at $180 /=$ ) and a flip chart tri-pond stand for Kenya shillings $600 /=$. In order to run an FFS effectively, one needs to build the capacity of staff or to engage competent/ qualified trainers. Their remuneration would depend on their level of formal education, experience, seniority and whether they are from the public or private sector. The FFS facilitators who are farmers earned less than well trained FFS facilitators from extension, research or other specialists. Although KTDA tea factories had no obligation to pay the salaries of such facilitators, they gave a facilitation allowance. KTDA factories gave FFS farmer-trainers a facilitation fee of 500/= per session and non-farmer trainers a facilitation fee of $1,000 /=$. The respondents proposed that a trainer from a research institution should be given a facilitation fee of $3,337 /=$, an extension agent $1,689 /=$ and a farmer facilitator $1,310 /=$. The FFS participants took some refreshments anytime they met for training costing $1733 /=$ per session and spent $2,639 /=$ to buy fertilizer for the demonstration plot. They also used $558 /=$ to buy pruning saws, $487 /=$ to buy watering cans, and $450 /=$ to compensate the host farmer for offering the 90 tea bushes used by FFS members for field experiments, 3,000/= for tea and snacks during meetings organized at the KTDA factories and 20,000/= for visiting and training in a research station. Most KTDA factories spent an average of 182,290/= to run a Farmer Field school per year, which translates to $6,076 /=$ or US $\$ 71$ (182,290/= divided by 30 FFS members) per farmer per year. In the opinion of most FFS members, this amount was inadequate and should be increased. They proposed an FFS budget of $231,746 /=$. This translates to $7,725 /=$ (US\$91/= at an exchange rate of US $\$ 1=\mathrm{Ksh} 85 /=)$ per farmer per year $(231,746 /=$ divided by 30 FFS members). 
PROBLEMS

OF EDUCATION

IN THE $21^{\text {st }}$ CENTURY

Volume 47, 2012

170

Table 1. Cost in Kenya shillings of conducting a Farmer Field School for 12 months ( $\mathbf{N}=514)$.

\begin{tabular}{|l|c|c|c|c|c|c|}
\hline Item & \multicolumn{3}{|c|}{ Proposed by farmers } & \multicolumn{3}{c|}{ Spent by a KTDA factory } \\
\hline & Unit cost & No & $\begin{array}{c}\text { Total } \\
\text { cost }\end{array}$ & Unit cost & No & $\begin{array}{c}\text { Total } \\
\text { cost }\end{array}$ \\
\hline Hiring a venue & 1,125 & 24 & 27,000 & 300 & 24 & 7,200 \\
\hline Flip chart & 400 & 1 & 400 & 400 & 1 & 400 \\
\hline Exercise books & 30 & 30 & 900 & 15 & 30 & 450 \\
\hline Pen & 30 & 30 & 900 & 15 & 30 & 450 \\
\hline File Folder & 30 & 30 & 900 & 15 & 30 & 450 \\
\hline 3 felt pens & 180 & 1 & 180 & 180 & 1 & 180 \\
\hline Flip chard/ tripod stand & 600 & 1 & 600 & 600 & 1 & 600 \\
\hline Paying researcher-led facilitator & 3,337 & 4 & 13,340 & 1,000 & 4 & 4,000 \\
\hline Paying extension-led facilitators & 1,689 & 24 & 40,536 & 1,000 & 24 & 24,000 \\
\hline Paying farmer-led Facilitator & 1,310 & 3 & 3,930 & 500 & 3 & 1,500 \\
\hline Estimated cost of refreshment & 1,733 & 24 & 41,592 & 1,733 & 24 & 41,592 \\
\hline Fertilizer, & 2,639 & 1 & 2,639 & 2,639 & 1 & 2,639 \\
\hline Pruning saws & 558 & 5 & 2,790 & 558 & 5 & 2,790 \\
\hline Watering cans & 487 & 5 & 2,435 & 487 & 5 & 2,435 \\
\hline FFS members tour costs to the factory & 20,000 & 1 & 20,000 & 20,000 & 1 & 20,000 \\
\hline FFS members tour to a research station & 20,000 & 1 & 20,000 & 20,000 & 1 & 20,000 \\
\hline $\begin{array}{l}\text { Compensation for 90 tea bushes x } 5 \\
\text { groups x 1kg/bush/year }\end{array}$ & 450 & 40 & 18,000 & 450 & 40 & 18,000 \\
\hline Hospitality costs (tea \& snack) & 3,000 & 2 & 6,000 & 3,000 & 2 & 6,000 \\
\hline $\begin{array}{l}\text { Cost incurred by the TESA's when train- } \\
\text { ing in FFS. }\end{array}$ & 2,467 & 12 & 29,604 & 2,467 & 12 & 29,604 \\
\hline Total costs & & & & & & 182,290 \\
\hline & & & & & & \\
\hline
\end{tabular}

NB: The current level of KTDA financial support for the FFS facilitators is inadequate and might not attract the quality and commitment of the qualified professionals required.

The KTDA Tea Extension Service Assistant (TESA) who trains tea farmers in an FFS, visits 30 farmers in the FFS group for two monthly sessions of two hours each. The TESA's opportunity cost in terms of the time spent in the training is based on the TESA's monthly salary and 8 hours' work per day. This comes to Kenya shillings $467 /=$, which is obtained by dividing a monthly salary of $28,000 /=$ by 30 days by 8 hours times 4 hours. The TESA gets $1,000 /=$ for training in an FFS per day $(500 /=$ for travel and $500 /=$ for lunch), which comes to $2,000 /=$ for the two monthly training sessions. Since a tea-based FFS has 30 members, the combined cost of training them would be Kenya shillings $2,467 /=(467+2000)$ or $82 /=$ Kenya shillings per farmer $(2467 /=$ divide by 30 farmers $)$.

Although the FFS learning takes an average of only two hours, participants spend more time preparing to attend and adjusting to do other things after the FFS session is over. The exact time that farmers spend before and after the training varied from farmer to farmer. Although this time is often not taken into account in calculating the cost of a tea-based FFS, it must be considered calculating the farmers' opportunity cost. Because most FFS members did not keep time, the FFS sessions often started later than scheduled and tended to take longer than planned, 
which means using the two hours to calculate the cost of farmers' time at the FFS are just a minimum. The FFS session often took longer and members coped by extending the session. They sometimes spend the whole morning or afternoon in FFS trainings but on average they spent three hours attending the FFS. This opportunity cost of the farmer's time in FFS could be used for income generating. For a farmer who earns 300/= per day and spends three hours attending an FFS, he would have to forgo an income of Kenya shillings 225/= (i.e. 300/= divide by 8 hours per day time 3 hours per session times 2 sessions per month). When a farmer's opportunity cost of attending an FFS (Kshs 225/=) is added to the cost of a TESA training a farmer in the FFS $(82 /=)$, the total cost per farmers was Kenya shillings $307 /=$ or US $\$ 3.6$, where US $\$ 1=$ Kshs $85 /=$.

While calculating the cost of a field day organized by KTDA to train farmers on tea, the researchers considered the cost incurred by six TESAs to administer the field day based on a TESA's monthly pay of 28,000/=, the TESA's transport expenses to the field day, participants' cost of food and refreshments, and participants' opportunity cost for attending the field day. Six field days, each lasting a full day, were being conducted every year in all the 6 electoral areas. The monthly cost of conducting a field day is $28,000 /=$ divide by 30 days times six TESAs is equals $5,600 /=(\mathrm{US} \$ 65.88)$ that trains 400 farmers. The cost of hiring trainers (usually six per field day) to conduct a mini tea-based field day per farmer is Ksh 14/= or US\$0.16 (Ksh 5600/= divide by 400 farmers). The cost of conducting a major tea-based field day (attended by 800 farmers) is Ksh $14 /=$ divide by 2 , which is equal to $7 /=$ or US\$0.08. KTDA spends $20,000 /=$ per mini field day and $120,000 /=$ for a major field day to cater for refreshments and transport. The amount spent per field day per farmer is equals to $(20,000 /=$ divide by 400 farmers and 120,000 divide by 800 farmers farmers) $50 /=$ and $150 /=$ respectively. Framers' opportunity cost of attending a field day, based on a farmer's pay per day, was 300/=. The total cost of educating a tea farmer in a mini field day therefore was $364 /=$ or US $\$ 4.28(14 /=$ plus $50 /=$ plus $300 /=)$. The total cost of educating a tea farmer in a major field day therefore was $457 /=$ or US\$5.38 $(7 /=$ plus $150 /=$ plus $300 /=)$.

While calculating the cost of training a tea farmer through a farm visit, a KTDA TESA is required to visit 100 farmers per month. The TESA's opportunity cost of making a visit to a farmer's farm is calculated on the basis of the TESA's monthly salary of $28,000 /=$ Kenya shillings. Assuming he can train 100 farmers (4 farmers per day for 25 days) in one month about tea, his opportunity cost would be equal to $280 /=(28,000 /=$ divided by 100 farmers $)$. The TESA receives $500 /=$ per day for travel and $500 /=$ for lunch in each of the 25 daily visits to farmers per month. The cost would be $(500+500) \times 25$ days $)$ or $25,000 /=$ per month divided by 100 farmers equals a cost of $250 /=(25,000 /=$ divided by 100 farmers $)$. In calculating the exact cost of a farm visit, one must consider the cost incurred by the extension agent and the opportunity cost that a farmer forgoes in order to welcome and receive training from the extension agent. The farmer's opportunity cost of participating in a training session on the farm was calculated on the basis of his or her average daily earning of $300 /=$, which covers eight working hours per day. The farm visit lasts an average of two hours which translates to a farmer's opportunity cost of $75 /=(2 \mathrm{hrs}$ divided by $8 \mathrm{hrs} \times 300 /=)$. When the farmer's opportunity cost $(75 /=)$ is added to a TESA's two hours' pay $(280 /=)$ and transport cost $(250 /=)$ it becomes $605 /=($ US $\$ 7.1)$, which is then the total cost of a two hours' field visit.

Smallholder farmers in this study (Figure 1) benefited from participating in the FFS through empowerment in sustainable farming, better tea husbandry, improved yields, social capital benefits and leadership skills. 
PROBLEMS

OF EDUCATION

IN THE $21^{\text {st }}$ CENTURY

Volume 47,2012

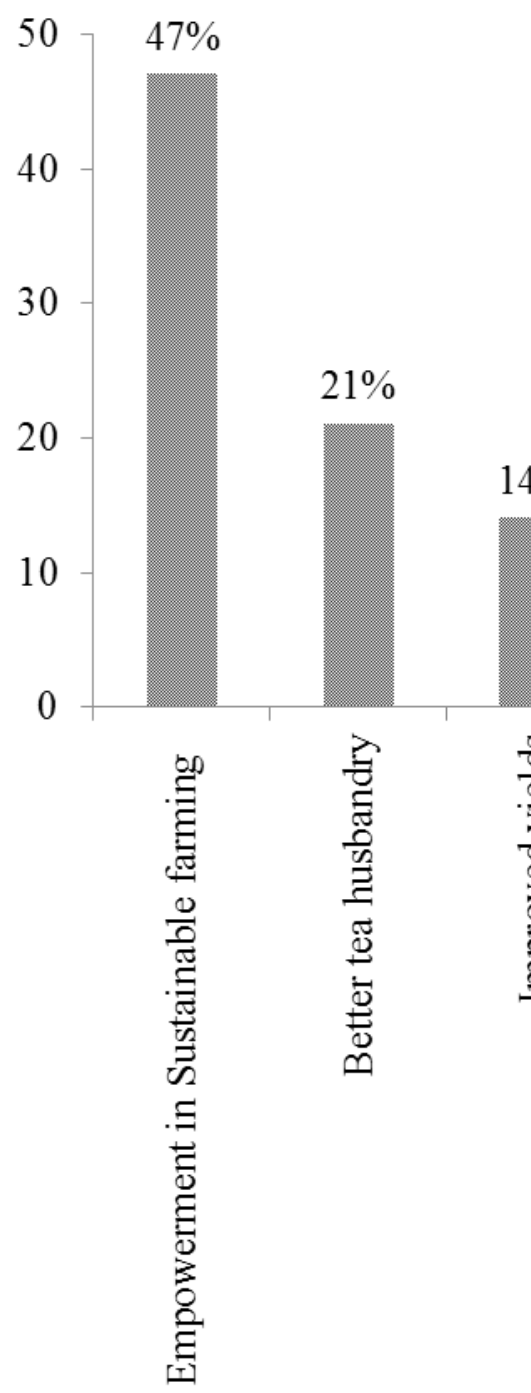

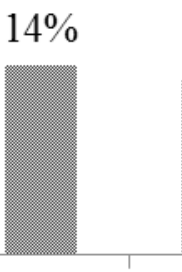

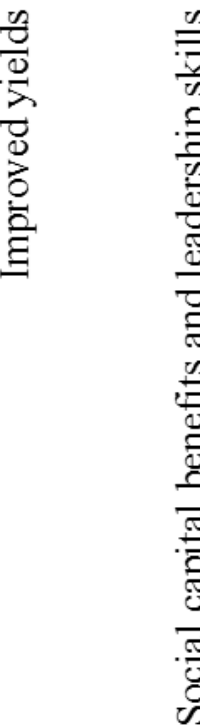

$13 \%$
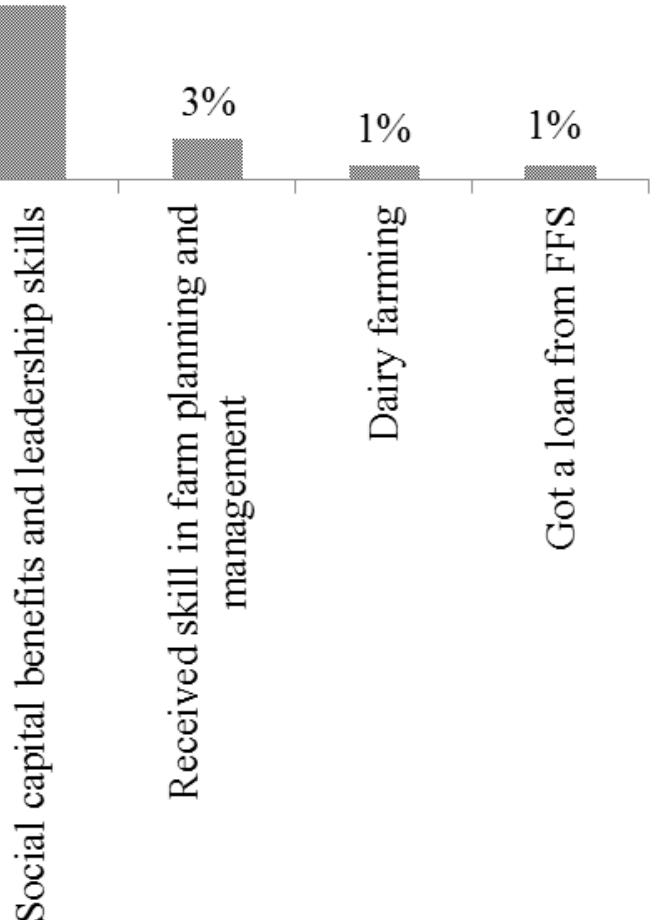

Figure 1: Farmers' benefits of participating in Farmer Field School trainings.

Over $84 \%$ of the smallholders recorded a good-to-excellent increase in yields and reduced tea plucking interval after training in FFSs', 78\% observed good-to-excellent change in improved public health, $76 \%$ observed a good-to-excellent increase in empowerment and increased savings while $62 \%$ observed increased ability to fund own activities (Table 2). However, $58 \%$ of the smallholders' ability to pay facilitators' costs remained poor, $33 \%$ of their ability to acquire affordable credit was poor, $31 \%$ of their ability to lobby through farmer networks (e.g. for better tea prices) was unchanged, $30 \%$ of their ability to pay operational costs did not improve, $27 \%$ of the smallholders said their chances for membership to a federation was poor. Twenty five percent were yet to market their farm produce as a group and $24 \%$ were yet to access linkages and networking with other groups. This lack of progress was probably because many FFS groups were still in the early stages of their curriculum and were yet to observe real changes in their livelihood. 


\section{Table 2. Farmers' observed changes in livelihood after training in a Farmer Field School $(N=514)$.}

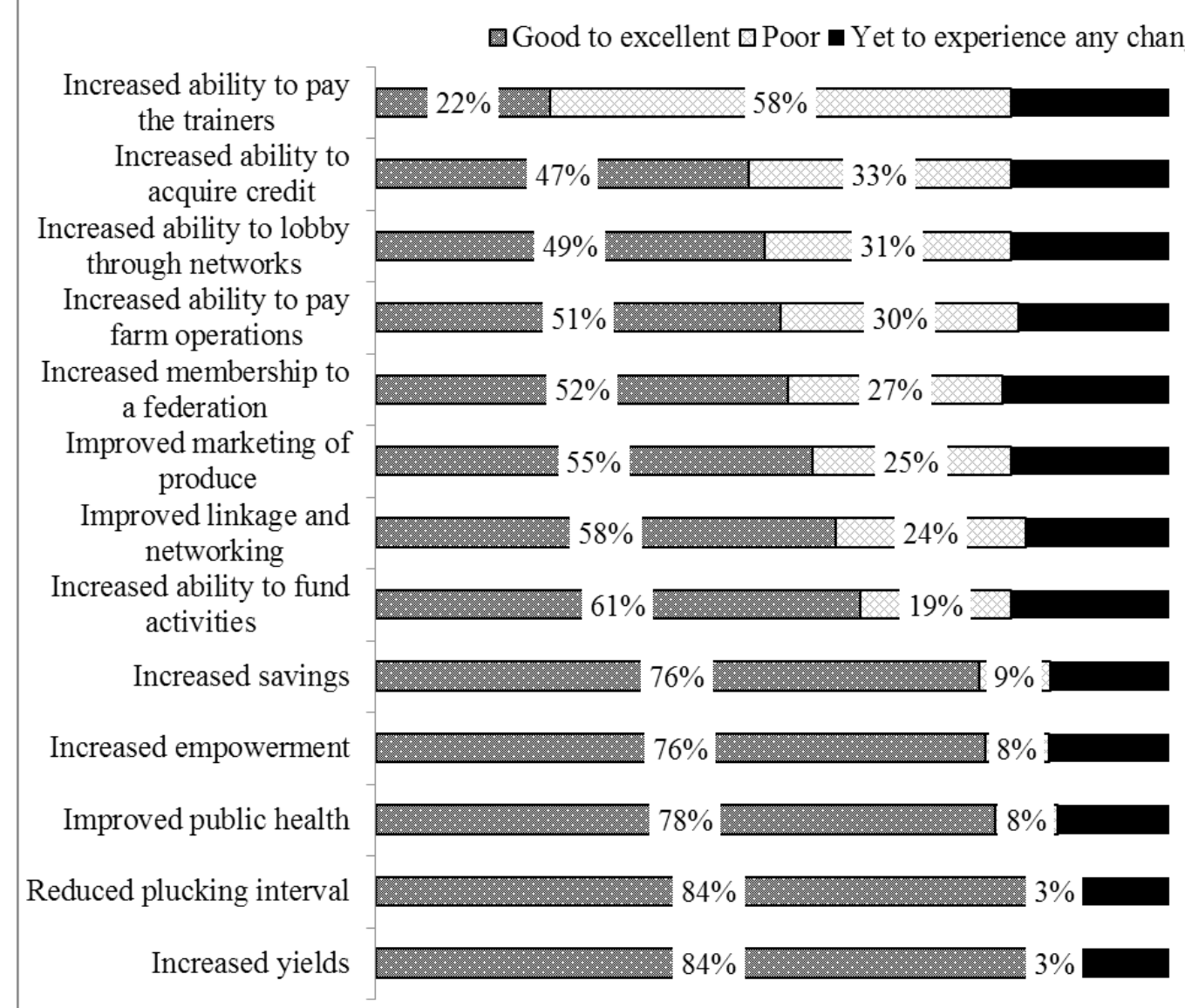

\section{Discussion}

Most KTDA factories spent an average of $182,290 /=$ to run an FFS per year, which translates to $6,076 /=(\mathrm{US} \$ 71)$ per farmer per year. This amount, in the opinion of most FFS members, was inadequate and should be increased. They proposed an FFS budget of 231,746/=, which translates to $7,725 /=(\mathrm{US} \$ 91 /=)$ per farmer per year. This cost is reasonable compared to Barbut (2011) who indicated the costs of establishing a new FFS to be $\$ 800$ and that of training a new FFS facilitator as $\$ 1350$. Van den Berg and Jiggins (2007) estimated the costs running a FFS in Indonesia and the Philippines as US\$62 and US\$48 per participant, respectively. According to Gallagher (2003), the cost of conducting a season-long field school for 25 farmers range from $\$ 150$ to $\$ 1,000$ depending on the country and the organization. Braun, Thiele and Fernández (2000) gave the average cost of a field school facilitated by a professional extension worker as US\$532. According to Braun and Duveskog (2010), FFSs can be expensive or low-cost depending on implementer and how they are conducted but costs per FFS decline as activities become routine, prices become lower due to bulk purchase of materials, and trainer and facilitator skills and experience increase. The results contradict the findings of Rusike et al., (2004), and that of Swanson and Rajalahti (2010) who considered FFSs as more costly to implement, labor-intensive extension model that reaches a small number of interested farmers.

The findings of the study confirm that group extension methods are cheaper than individual extension methods in the training of tea farmers. Among the three methods considered, 
PROBLEMS

OF EDUCATION

IN THE $21^{\text {st }}$ CENTURY

Volume 47, 2012

174 FFS was the cheapest (US\$3.6 per farmer) followed by field days (US $\$ 4.28$ for a mini field day and US\$5.38 for a major field day) and farm visits (US\$7.1 per farmer), which were the most expensive. The research findings showed that the cost of running a tea-based FFS was cheaper compared to that of a field day and farm visit. These results contradicts the findings of Bunyatta, Mureithi, Onyango and Ngesa, (2006) who noted that high training costs take up a large portion of the FFS recurrent budget. While comparing the FFS approach with the farm visit in Zanzibar, Endalew (2009) noted that FFSs have many promising attributes which gives it much higher chances of effectiveness as an extension methodology in Sub-Saharan African than farm visits. According to him and in the opinion of most FFS members, FFS graduates accrue additional, difficult-to-quantify, benefits which can be difficult to quantify in monetary forms such as gaining superior leadership skills and become more cohesive as a group than nonFFS farmers. Rusike et al. (2004) concurs that FFS trainings provided more opportunities for experimentation and collective learning-by-doing that improves farmers' understanding of new technologies, their capacity to effectively use the technologies and to make better decisions, and improves adoption rates. International Initiative for Impact Evaluation (2010), suggested that FFSs can be a cost - effective way of increasing farmers' skills. Smallholder farmer derived a lot of benefits from participating in the FFS through empowerment, group cohesion and gaining superior leadership skills in sustainable farming, better tea husbandry, improved yields, social capital benefits and leadership skills. FFS-trained farmers benefited from increased tea yields, improved farmer empowerment and health as well as increased savings and improved selfreliance.

\section{Conclusions}

Based on the findings of the study, the researchers concluded that training tea farmers in FFS was cheaper and more effective in bringing behavioral change related to adoption of agricultural technologies compared to field days and farm visits. They also concluded that FFSs provided farmers many learning opportunities and could be up-scaled in a sustainable manner because they involved farmers in decision making and in contributing the resources required for training. The researchers further concluded that smallholder tea farmers trained in FFS benefited from better tea husbandry, reduced plucking interval, improved tea yields, increased empowerment and enhanced leadership skills. The researchers recommended that tea stakeholders such as Kenya Tea Development Agency, The Sustainable Trade Initiative, and the Kingdom of Netherlands Embassy, among others, should continue using FFS in the training of tea farmers. They should also invest more in the development of more FFS and should encourage other development partners particularly in the private sector such as tea buyers, NGOs and willing sponsors to financially support the current initiative of up-scaling tea-based FFSs.

\section{Acknowledgements}

We would like to pass our sincere gratitude to staff at ETC-East Africa and the Embassy of the Kingdom of the Netherlands in Kenya for awarding us the research funds and to fellow colleagues at the Department of Agricultural Education and Extension, the Dean of the Faculty of Education and Community Studies; and the Director of Graduate School of Egerton University for ascertaining the questionnaire's content validity, and to all smallholder tea farmers and all KTDA field extension officers involved in the study for their support. 
Stephen WAMBUGU MAINA, John GOWLAND-MWANGI, Dave BOSELIE. Cost and Benefits of Running a Tea-Based Farmer Field School in Kenya

\section{References}

Akinnagbe, O. M., Ajayi, A. R. (2010). Challenges of farmer-led extension approaches in Nigeria. World Journal of Agricultural Sciences 6 (4): 353-359, 2010 ISSN 1817-3047. IDOSI Publications.

Asian Productivity Organization (2006). Enhancement of extension systems in agriculture. Report of the APO seminar on enhancement of extension systems in agriculture held in Pakistan, 15-20 December 2003 edited by Dr. V.P. Sharma. Retrieved on $18^{\text {th }}$ December 2010 from http://www. apo-tokyo.org/00e-books/AG-16_EnhanceExtSystem.htm

Barbut, M. (2011). Global environment facility. Washington, DC. USA.

Braga, T., Lonescu-Somer, A., Seifert, R. (2011). Case study. Unilever sustainable tea Part II: Reaching out to smallholders in Kenya and Argentina. Dutch Sustainable Trade Initiative.

Braun A., Duveskog, D. (2010). The farmer field school approach - History, global assessment and success stories. Background paper for the IFAD rural poverty report 2010.

Braun, A, R., Thiele, G., Fernández, M. (2000). Farmer field schools and local agricultural research committees: complementary platforms for integrated decision-making in sustainable agriculture. Agricultural Research \& Extension Network No.105.

Bunyatta, D. K., Mureithi, J. G, Onyango, C. A., Ngesa, F. U. (2006). Farmer field schools effectiveness for soil and crop management technologies in Kenya, Njoro, Kenya. Retrieved on $13^{\text {th }}$ December 2010 from http://www.aiaee.org/attachments/159_Vol-13.3.pdf

Campbell, C. (2010). Agricultural Man Ecology Foundation (AME): Farmer Field School. Development Dialogue 2010.

Davis, K., Nkonya, E., Mekonnen, D. A., Odedo, M., Miiro, R., Nkuba, J. (2010). Impact of FFS on agricultural productivity and poverty in East Africa. IFPRI Discussion Paper 00992 June 2010.

De Jager, A., Onduru, D. D., Hiller, S., Van den Bosch, R. (2009). Sustainability of smallholder tea production in developing countries: Experiences from Kenya .

Dzeco, C., Amilai, C., Cristóvão, A. (2010). Farm field schools and farmer's empowerment in Mozambique: A pilot study. 9th European IFSA Symposium, $4 \square 7$ July 2010, Vienna (Austria).

Endalew, B. D. (2009). Effectiveness of farmer field school in promoting coffee management practices: The case of Jimma and Sidama zones. Msc. thesis. Haramaya University.

Food and Agriculture Organization (2011). Educational foundations of the field school. Ten years of IPM training in Asia. From farmer field school to community IPM. Downloaded on $9^{\text {th }}$ February, 2011 from http://www.fao.org/docrep/005/ac834e/ac834e07.htm

Friis-Hansen, E., Duveskog, D., Taylor, E. W. (2012). Less noise in the household: the impact of Farmer Field Schools on Gender Relations. Journal of Research in Peace, Gender and Development, 2 (2), 044-055. http://www.interesjournals.org/JRPGD

Gallagher, K. (2003). Fundamental Elements of a Farmer Field School. Low External Input Sustainable Agriculture Magazine.

Government of Kenya (2011). Agricultural sector development support programme. Programme document. Ministry of Agriculture. Nairobi, Kenya.

Hartl, M. (2009). Technical and vocational education and training (TVET) and skills development for poverty reduction - do rural women benefit? Paper presented at the FAO-IFAD-ILO Workshop on Gaps, trends and current research in gender dimensions of agricultural and rural employment: differentiated pathways out of poverty Rome, 31 March - 2 April 2009. International Fund for Agricultural Development, Italy. Retrieved January 27 from http://idosi.org/wjas/wjas6(4)/3.pdf

Hiller, S., Onduru, D. D., \& Jager, A. (2009). Sustainable tea production. An assessment of farmer field school in Kenya. Retrieved on $8^{\text {th }}$ January 2011 from http://edepot.wur.nl/5554

Kilimo Trust (2010). Deepening and scaling-up the MATF initiative: Round 5 grants. Nairobi, Kenya: Ministry of Agriculture.

Kothari, C. R. (2008). Research methodology: Methods and techniques, (pp. 1-56). New Delhi: New Age International (P) Limited, Publishers. 
PROBLEMS

OF EDUCATION

IN THE $21^{\text {st }}$ CENTURY

Volume 47, 2012

176 Maina, W. S., Mwangi, J. G., Boselie, D., Onduru, D., Buses, B. C. (2012a). Up-scaling Farmer Field Schools and Rainforest Alliance certification among smallholder tea producers in Kenya: Options, opportunities and emerging lessons. Problems of Education in the $21^{\text {st }}$ Century, 43 (43), 141-158.

Maina S. W., Buses, B. C., Mwangi, J. G., Boselie, D., Onduru, D., Waarts, Y. (2012b). System Design and Scalability of Farmer Field Schools and Rainforest Alliance Certification of Smallholder Tea Producers East and West of Rift Valley. A Research Report on the Scalability of Sustainable Tea Value Chain project in Kenya

Mosby's Dental Dictionary, 2nd edition (2008). Cross-sectional study. http://en.wikipedia.org/wiki/ Cross-sectional_study

Mugambi, K. (2010). Tea export earnings defy drought to hit Sh69 Billion. Retrieved on $13^{\text {th }}$ December 2010 from http://allafrica.com/stories/201001261008.html

Muller, I., Guenat, D., Fromm, I. (2010). Impact monitoring and evaluation system for farmer field schools in Kyrgyzstan: How to optimize resource allocation for higher impact. Journal of Agricultural Education and Rural Development 2 (10): 211-218; available online: Available online http:// academicjournals.org/JAERD. Retrieved $20^{\text {th }}$ December 2010 from http://www.tropentag. de/abstracts/full/475.pdf

Mutai, P. (2011). Kericho County: The evergreen county that produces high quality tea. The Standard on Sunday, Sunday $9^{\text {th }}$ January 2011. Mombasa Road, Nairobi: The Standard Ltd.

Mwangi, J. G., Oloo, J. O., Maina, S. W. (2010). The effectiveness of Farmer Field Schools' extension methodology in soil and water conservation using contour ploughing, unploughed strips, and farm yard manure. Problems of Education in the $21^{\text {st }}$ Century, 26 (26), 52-65.

Odhiambo, A. (2010). Kenya tea export grows by 50\%. Business Daily Sunday December 12, 2010. Retrieved on $13^{\text {th }}$ December 2010 from http://www.businessdailyafrica.com/CompanyIndustry/ Kenyateaexportgrowsby50percentindex.html.

Ricker-Gilbert, J. (2005). Cost-Effectiveness Evaluation of Integrated Pest Management (IPM) Extension Methods and Programs: The Case of Bangladesh. Thesis Submitted to the faculty of the Virginia Polytechnic Institute and State University in partial fulfillment of the requirements for the degree of Masters in Science In Agricultural and Applied Economics.

Rusike, J., Masendeke, D., Twomlow, S. J., Heinrich, G. M. (2004). Impact of Farmer Field Schools on adoption of soil water and nutrient management technologies in dry areas of Zimbabwe. Global Theme on Agro- Ecosystems, Report no. 14. PO Box 776, Bulawayo, Zimbabwe: ICRISAT. pp:24.

Stigter, K. (2010). A plea for climate field schools in China. INSAM, International Society for Agricultural Meteorology.

Swanson, B. E., \& Rajalahti, R. (2010). Strengthening Agricultural Extension and Advisory Systems: Procedures for Assessing, Transforming, and Evaluating Extension Systems. Agriculture and Rural Development Discussion Paper 44. The International Bank for Reconstruction and Development/ The World Bank. Retrieved Feb 16 from http:/www.g-fras.org/fileadmin/UserFiles/Documents/ Frames-and-guidelines/M_E/Strengthening-Agricultural-Extension-and-AS.pdf.

Van den Berg, H \& Jiggins , J. (2007). Farmer Field Schools reap long-term rewards. Pesticide News 78 and paper in World Development 35:663-686. Retrieved on $28^{\text {th }}$ December 2010 from http://www. pan-uk.org/archive/projects/Fairness/PN/pn78pp6-7.pdf

Wani, G. M. (2008). Extension Education Reformation - I - New Reformation Models http://www.articlesbase. com/science-articles/extension-education-reformation-i-new-reformation-models-331861.html

Wanyama, J. M., Mose, L. O., Mutoko, C. M., Wanyonyi, M., Nyambati, E., Wanjekeche, E., Rono, S. (2007). Assessing factors influencing farmers to join and participate in farmer research groups in the North Rift Region of Kenya. Kitale. Kenya. Retrieved on $28^{\text {th }}$ December 2010 from http://www. kari.org/filesadmin/publications/10thProceedings/Volone/AssessingFactors.pdf 
Stephen WAMBUGU MAINA, John GOWLAND-MWANGI, Dave BOSELIE. Cost and Benefits of Running a Tea-Based Farmer Field School in Kenya

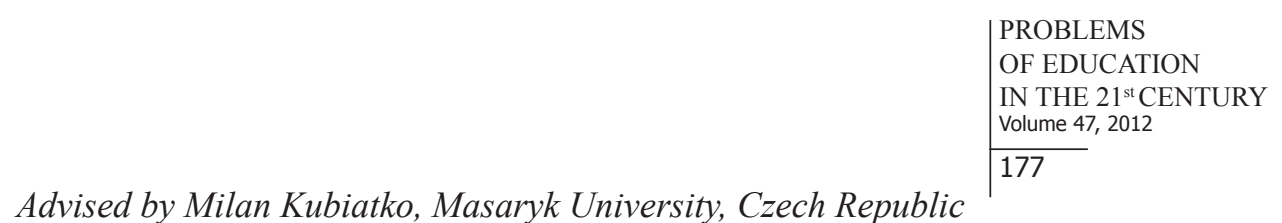

Received: August 30, 2012

Accepted: September 30, 2012

\begin{tabular}{|ll|} 
Stephen Wambugu Maina & MSc in Agricultural Extension, Principal Agricultural Officer, Ministry of \\
& $\begin{array}{l}\text { Agriculture - Narok South District, P. O. Box 15428-20100 Nakuru, Kenya. } \\
\text { Phone +254-(0)722379440; +254-(0)735456734 } \\
\text { E-mail: stephen67maina@yahoo.com }\end{array}$ \\
\hline John Gowland-Mwangi & $\begin{array}{l}\text { PhD in Agricultural Education and Extension, Professor of Agricultural } \\
\text { Education and Extension and Deputy Vice Chancellor (Research \& Exten- } \\
\text { sion), Egerton University, P. O. Box 536-20115 Egerton, Kenya. } \\
\text { Phone: +254-(0)723 466733; (0)732 241 089; (0)722-958069. } \\
\text { E-mail: mwangijg5@yahoo.com; dvcre@egerton.ac.ke }\end{array}$ \\
\hline Dave Boselie & Director Learning and Innovation, IDH, The Sustainability Initiative Utrecht, \\
The Netherlands. \\
E-mail: Boselie@idhsustainabletrade.com
\end{tabular}

